\section{Molecular and Structural Evaluation of Dentin Caries-Like Lesions Produced by Different Artificial Models}

Larissa Ferreira Pacheco' , Éfani Caroline de Freitas Banzi' , Eliana Rodrigues', Luis Eduardo Silva Soares ${ }^{2}$. Fernanda Miori Pascon'1, Lourenço CorrerSobrinho ${ }^{3}$, Regina Maria Puppin-Rontani ${ }^{1}$

\author{
'Department of Pediatric Dentistry, \\ Piracicaba School of Dentistry, \\ UNICAMP - University of \\ Campinas, Piracicaba, SP, Brazil \\ ${ }^{2}$ Department of Dental Materials and \\ Operative Dentistry, Vale do Paraiba \\ University; School of Dentistry, \\ Research and Development Institute, \\ IPED, Laboratory of Biomedical \\ Vibrational Spectroscopy, LEVB. \\ São José dos Campos, SP, Brazil \\ ${ }^{3}$ Department of Restorative \\ Dentistry, Dental Materials \\ Division, Piracicaba School of \\ Dentistry, UNICAMP - University of \\ Campinas, Piracicaba, SP, Brazil
}

Correspondence: Profa. Dra. Regina Maria Puppin-Rontani, Avenida Limeira, 901, 13414-903 Piracicaba, SP, Brasil. Tel: +55-19-2106-5286. e-mail: rmpuppin@fop.unicamp.br

Key Words: dentin, hardness, scanning electron microscopy, Fourier-transformed Raman spectroscopy, energy dispersive $\mathrm{x}$-ray spectroscopy.

\section{Introduction}

Caries-affected dentin is an important substrate to be considered in studies targeting on remineralization/ demineralization procedures, prevention of caries lesions progression, caries removal and restorative materials bonding to dentin, since it is the substrate mostly found in clinical procedures $(1,2)$. Caries produced by in vitro models attempt to mimic caries-like lesion observed in vivo and they have been designed for clinical and mechanical purposes $(3,4)$. However, several factors related to substrate, such as human vs. bovine enamel, sound vs. demineralized tissues, lesion type and depth, severity of cariogenic challenge and microflora, may influence the reactivity of hard tissue, and hence lesion development and progression, providing variability in research results as seen in the literature (4-6).

Several studies used dentin modified substrate for different methodologies to produce dentin caries-like lesions in vitro, in an attempt to simulate the caries-affected or carious dentin, and they are used in bond strength tests, remineralization studies and secondary caries inducing in restored teeth $(5,7,8)$. However, it is known that the most important issue to be considered in all those experiments is the substrate used, since it is directly related to mineral content and distribution, morphology, tissue structure and substrate reactivity, which are highly dependent on those characteristics (9).

There are different types of in vitro caries-like lesion induction models and they have different patterns of development. These approaches used acidic gels (7), buffered solutions (10) and microbiological models (7). Some studies $(5,11)$ used them as a useful parameter for the assessment and comparison of de- or remineralization mechanism and obtaining information of these two correlated processes during caries lesion formation, mineral loss and caries progression $(5,11)$.

Chemical models comprising demineralizing solutions is a so-called static model and may be used for caries induction. However, the literature showed that caries lesion results from demineralizing and remineralizing episodes and it is highly dependent on fluoride content in oral fluids and hard tissue $(5,7)$. Therefore, there are $\mathrm{pH}$-cycling models that try to reproduce de- and remineralization cycles and are considered relatively simple to perform and inhibit the saturation with constant changes $(5,7,12)$, producing a substrate similar to a caries-affected dentin layer after infected dentin caries removal. However, this 
method cannot simulate all factors involved in the natural process, such as biofilm, saliva and collagen degradation. In addition, caries-like lesions produced by $\mathrm{pH}$-cycling showed similarity with the natural ones concerning only hardness (13) and morphology $(7,11)$.

Use of microorganisms as acid producers in cultures for induction of caries-like lesions is known as biological model, since it is widely accepted that Streptococcus mutans plays an important role in both development of primary and secondary caries (14). Although this method may promote a constant unsaturated environment without any exchange with oral environment, which involves presence of fluoride, nutrition, quality and quantity of saliva, it reproduces an acidic environment provided by biofilm presence $(15,16)$.

Another model for caries like-lesion production, closely resembling those that occur naturally, is an in situ model that seems to be promising, since it involves a natural environment, with mineral exchange, microbial virulence factors, food cariogenicity, remineralizing agents and enzymes present in saliva. Considering the multi-factorial nature of dental caries, the in situ model can simulate in a short time what may happen in the oral environment associated with controling experimental variables, but differences concerning composition of saliva, eating patterns and food retention must also be considered $(15,16)$.

Previous studies $(9,15)$ investigating aspects of dentin caries demonstrated that artificial dentin caries resemble natural dentin caries, both histologically and microradiographically, since both involve subsurface mineral loss, producing different zones. From the outer surface, the first layer is a well mineralized surface zone, followed by an area of increased demineralization (lesion body) (15). However, it should be emphasized that artificial dentin caries represents usually only a single demineralization phase. This contrasts with the natural dentin carious process where the lesion would have gone through many de- and remineralization cycles $(1,2)$.

Although most bond strength testing has been done on normal dentin for convenience, clinically most bonding substrates are not sound, but rather than are cariesaffected dentin or sclerotic dentin. Unfortunately, few studies have been published on these clinically relevant substrates due to the difficulty to standardize the natural carious substrate $(1,17)$. Few earlier studies attempted to simulate properties and characteristics of sclerotic or cariesaffected dentin in vitro $(5,17)$. There has been a paradigm shift on the clinical treatment of deep caries lesions. It is now acceptable to leave behind caries-affected or even caries-infected dentin during restorative procedures (18). Marquezan et al. (2009) (5) assessed the ability of chemical and a microbiological models to produce artificially dentin caries-like lesions similar to natural ones in primary molars using microhardness and morphological analysis. However, further analyses should be conducted on molecular composition of these substrates in permanent teeth.

In addition, the development of methodologies for easy and standardized in vitro studies with caries-like lesion production is a very important challenge, mainly nowadays, where techniques and materials are improved or created and need be tested. Therefore, to study the behavior and properties of dentin, it is necessary that models of carieslike lesion production simulate the conditions of dental substrate $(18,19)$.

In searching for a caries production model that mimetizes caries lesion characteristics produced in vivo (natural caries lesions), the aim of this study was to evaluate dentin caries-like lesions produced by different artificial models compared to natural caries lesions. The tested hypothesis is that different models of development of dentin caries-like lesions provide different microhardness, depth, organic and inorganic content and structure from natural dentin caries.

\section{Material and Methods Specimen Preparation}

This study was performed under the protocol number 111/2005 approved by the Ethics Committee of Piracicaba School of Dentistry, University of Campinas, Brazil.

Dentin blocks $(4 \times 4 \times 2 \mathrm{~mm})$ were prepared from human third molars (124 sound and 47 carious) that were stored in $0.1 \%$ tymol solution. Sound dentin blocks were polished with 1200-grit silicon carbide abrasive paper (Carbimet Disc Set; Buehler UK LTD, Lake Bluff, IL, USA) and the initial surface Knoop analyzed hardness was set as baseline $\left(\mathrm{SH}_{1}\right)$ using an indenter under a $25-\mathrm{g}$ load for $10 \mathrm{~s}$. Five indentations (Shimadzu HMV-2000; Shimadzu Scientific Instruments, Kyoto, Japan), spaced $100 \mu \mathrm{m}$ from each other were made on the block surface. Sound dentin blocks were divided into three groups considering artificial caries development models: GB: Biological Model - Dentin artificial caries lesions produced by $S$. mutans biofilm $(n=47) ;$ GC: Chemical Model - Dentin artificial caries lesions produced by acid gel ( $n=47) ; \mathrm{GIS}$ : In situ Model - dentin artificial caries lesions produced in situ $(n=30)$; GNC: - Natural caries lesions (control) - Extracted teeth with dentin caries lesions $(n=47)$.

\section{Artificial Caries Development Models}

Biological model (GB). The dentin blocks were fixed with orthodontic wire on the lids of glass vials containing $22 \mathrm{~mL}$ of sterile distilled water and were taken to the Nuclear Energy enter for Agriculture, University of São Paulo (Piracicaba, SP, Brazil) to be subjected to gamma radiation sterilization (20) in a dose of $14.5 \mathrm{kGy}$ - for 
$12.5 \mathrm{~h}$ (7). The room temperature was kept constant $(27$ ${ }^{\circ} \mathrm{C}$ ) and then transferred to another glass vial containing $22 \mathrm{~mL}$ of sterile brain-heart infusion (BHI) broth (Becton Dickinson and Company, Sparks, MD, USA) supplemented with yeast extract (Himedia Laboratories; PVT Ltd., Mumbai, India), with 0.5\% glucose (Synth; LabSynth, São Paulo, SP, Brazil), 1\% sucrose (LabSynth) and 2\% S. mutans (UA159) for artificial carious lesions development (7). The concentration of the bacterial suspension was determined by measuring absorption at $660 \mathrm{~nm}$ (A660) (21). In order to adjust the number of viable bacteria to A660, the number of colony-forming units per milliliter of bacterial suspension (cfu/mL) was determined with the use of standard spreading techniques at carious optical densities (21). Inoculation occurred only in the first day of the experiment, but the broth was renewed every $48 \mathrm{~h}$ during 14 days. Contamination of the broth was checked every day using Gram staining.

Chemical model (GC): The blocks were immersed in $5 \mathrm{~mL}$ of 6\% carboximethylcellulose acid gel (Proderma Pharmacy, Piracicaba, SP, Brazil) containing $0.1 \mathrm{M}$ lactic acid titrated to $\mathrm{pH} 5.0$ with a concentrated $\mathrm{KOH}$ solution at $37{ }^{\circ} \mathrm{C}$. The specimens remained in the gel for 14 days without renewal (22).

In situ model (GIS): Five healthy volunteers with normal salivary flow and who did not violate the exclusion criteria (use of any medication likely to interfere with salivary secretion, use of fixed or removable orthodontic appliances, pregnant or breastfeeding, smoker or systemic illness) were selected and after reading, signed an informed consent statements prior to study initiation. Five acrylic palatal appliances were prepared with six slots $(5 \times 5 \times 2 \mathrm{~mm})$ for each appliance, where the sterile dentin blocks were set. They were covered with a plastic grid attached $1 \mathrm{~mm}$ away from the block to allow the accumulation of dental biofilm (23). The volunteers used the device continuously (day and night) during 14 days. Removal of the intraoral palatal appliance occurred only during meals. Written guidelines were given to the volunteers emphasizing the non-use of products containing fluoride. The usual tooth brushing and the brushing of inner surface of the device were made with a standard fluoride-free dentifrice. To simulate the cariogenic challenge, a drop of $20 \%$ sucrose solution was placed in each block of dentin and 5 min later the device was put back in the mouth, and the frequency and time drip determined (eight times per day). After 14 days, dentin blocks were removed from the palatal appliance (23) and subjected to analysis.

\section{Dentin Block Analyses}

All dentin blocks (biological, chemical, in situ models and natural ones) were submitted to surface Knoop hardness
$\left(\mathrm{SH}_{2}\right)$, energy dispersive $\mathrm{X}$-ray spectroscopy ( $\mu \mathrm{EDXRF}$ ) and Fourier-transformed Raman spectroscopy (FT-Raman) analysis.

\section{Surface knoop hardness $\left(\mathrm{SH}_{2}\right)$}

Dentin blocks of natural caries lesion and the ones submitted to artificial caries development were polished with silicon carbide abrasive paper (Buehler) and $\mathrm{SH}_{2}$ was measured using a Shimadzu HMV-2000 (Shimadzu Scientific) indenter under a 25 -g load for $10 \mathrm{~s}$, as described above.

\section{Cross-sectional microhardness test (CSH)}

After $\mathrm{SH}_{2}$ analysis, all blocks were longitudinally sectioned through the center of carious lesion using a water-cooled low-speed diamond saw (Isomet, Buehler) providing two halves (7). One half of each block was randomly chosen, embedded in acrylic resin (Buehler Transoptic Powder), polished with 400-, 600- and 1200-grit silicon carbide abrasive paper (Carbimet Disc Set, Buehler) and cloth-polished with 1.0- $\mu \mathrm{m}$ diamond paste (Buehler Metadi II; Buehler). Next, the CSH test was performed using the same Knoop diamond tip, load and time as used for $\mathrm{SH}$ test. Four columns of eigth indentations each were made at the following depths: 10, 30, 50, 70, 90, 110, 220 and $330 \mu \mathrm{m}$ from the surface.

\section{$\mu \mathrm{EDXRF}$}

Semi-quantitative analysis of the calcium ( $\mathrm{Ca}$ ) and phosphorus $(P)$ elements were performed with the energy dispersive $x$-ray spectrometer (EDX $\mu-1300$, Shimadzu) equipped with an $\mathrm{X}$-ray tube at $15 \mathrm{kV}$, automatic chain and $50 \mathrm{~mm}$ beam diameter. The spectrometer was coupled to a computer for processing and data collection. The equipment was calibrated and adjusted using commercial hydroxyapatite [Sigma-Aldrich, synthetic $\mathrm{Ca}_{10}\left(\mathrm{PO}_{4}\right)_{6}(\mathrm{OH})_{2}$ ] as reference.

Five points distant $200 \mu \mathrm{m}$ from each other, located in the center of the dentin specimen were measured with a resolution of $20 \mu \mathrm{m}$. Data were collected using parameters of X-ray emission of $\mathrm{Ca}$ and $\mathrm{P}$. The oxygen ( 0 ) and hydrogen $(H)$ elements were used for chemical balance $(7,24,25)$.

In addition, element mapping was performed (50 kV, $1 \mathrm{~s}$ per point, $80 \times 60$ points, with $20 \mu \mathrm{m}$ increments) in one randomly chosen specimen of each group to obtain the surface distribution of elements ( $\mathrm{Ca}$ and $\mathrm{P}$ ) after caries lesion development and for natural lesions.

\section{FT-Raman}

Molecular measurements were performed on FT-Raman Spectrometer RF 100/S ${ }^{\circledast}$ (Bruker Optics Inc., Karlsruhe, Germany) with a germanium detector cooled by liquid 
$\mathrm{N}_{2}$. Samples were excited by an air-cooled Nd:YAG laser $(\lambda=1064.1 \mathrm{~nm})$ with $200 \mathrm{~mW}$ power. Spectral resolution was set at $4 \mathrm{~cm}^{-1}$. Three spectra were collected by 100 scans for each area (25).

Changes of organic and inorganic dentin components were analyzed by comparing the integrated areas of the Raman peaks centered at 350 to $520 \mathrm{~cm}^{-1}$ (phosphate), 978 to $1160 \mathrm{~cm}^{-1}$ (carbonate), 1540 to $1740 \mathrm{~cm}^{-1}$ (collagen type I) and 2800 to $3150 \mathrm{~cm}^{-1}$ (CH bond). The integrated areas of the peaks were calculated by Microcal Origin $5.0^{\circ}$ software (Microcal Software, Inc., Northampton, MA, USA).

\section{Scanning Electron Microscopy Evaluation (SEM)}

The other half of each block was prepared for SEM evaluation (7). Specimens were mounted on aluminum stubs with double-sided carbon tape (SEM, Nisshin EM Co. Ltd., Tokyo, Japan), and sputter coated at $10 \mathrm{~mA}$ for $2 \mathrm{~min}$ (SCD050 sputter coater, Balzers, Liechtenstein). They were observed under a SEM (JSM 5600LV; JEOL, Tokyo, Japan) at an accelerating voltage of $10 \mathrm{kV}$ and working distance of $20 \mathrm{~mm}$. From each dentin specimen, one image was obtained in a low magnification (25x) in order to identify a whole dentin caries lesion and establish its deepest region. Then, in a higher magnification (200x) measurement at the deepest point was accomplished in $\mu \mathrm{m}$. Intra-examinator calibration was performed to evaluate the coincidence level. Measurements were made twice in $20 \%$ of randomly chosen samples and coincidence level was $99 \%$.

\section{Statistical Analysis}

Data from $\mathrm{SH}_{1}$ were submitted to unpaired t-test and from $\mathrm{SH}_{2}$ were submitted to paired t-test to compare the groups. Data obtained in CSH were submitted to two-way ANOVA and Tukey's tests. Data obtained by SEM were submitted to one-way ANOVA and t tests. A significance level of $5 \%$ was set for all analyses. Measurements obtained from integrated area under FT-Raman peaks were analyzed using Instat software (GraphPad Software Inc., San Diego, CA, USA). One-way ANOVA test at a 95\% confidence level and the Dunnett Multiple Comparisons test were applied

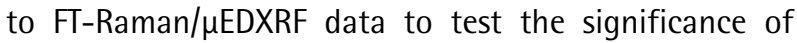
integrated area evaluation between natural caries lesion and caries-like lesions (BioEstat 5.0, Belém, PA, Brazil).

\section{Results}

\section{SH Analysis}

Table 1 shows the means and standard deviations (SD) of $\mathrm{SH}_{1}$ and $\mathrm{SH}_{2}$ values. Statistical analysis showed no difference in the baseline values $\left(\mathrm{SH}_{1}\right)$ for $\mathrm{GB}, \mathrm{GC}$ and GIS groups ( $p>0.05$ ). Concerning $\mathrm{SH}_{2}, \mathrm{~GB}$ and $\mathrm{GNC}$ showed significantly lower surface hardness values compared with GC and GIS $(p<0.05)$. There was significant difference between all groups when $\mathrm{SH}_{1}$ was compared to $\mathrm{SH}_{2}$.

\section{$\mathrm{CSH}$}

Regarding CSH analysis, two-way ANOVA statistical analysis showed that there was no significant interaction between the studied factors (artificial caries development methods/natural lesions and caries depths) ( $p>0.05)$. Concerning artificial caries development methods, no significant difference was observed between GIS and GNC (control group) and GBand GNC ( $>0.05$ ) (Table 2). Regarding demineralization depth, the lowest values were observed at $10 \mu \mathrm{m}$ and $30 \mu \mathrm{m}(\mathrm{p}>0.05)$, considered as cariesinfected dentin. Increase in $\mathrm{CSH}$ values was observed with the increase of depth (Table 2).

\section{$\mu E D X R F$ Analysis}

Regarding $\mathrm{Ca}$ and $\mathrm{P}$ weight percentages, GIS showed significantly higher values than GB and GNC. In addition, GC was similar to GIS and GNC (Table 3). The obtained mapping images of different caries lesions by area mapping showed similarity among GB and GNC, followed by GIS regarding element distribution pattern for the $\mathrm{Ca}$ and $\mathrm{P}$ content. In contrast, GC showed areas that were related with greater mineralization (Fig. 1).

\section{FT-Raman Analysis}

Concerning FT-Raman spectroscopy results, Table 3 showed no significant difference among all groups to phosphate, carbonate and $\mathrm{CH}$ bonds values. However, regarding type I collagen, there was a statistically significant difference to GC compared all other groups.

\section{SEM Analysis}

Caries lesions depth $(\mu \mathrm{m})$ observed at SEM showed that natural (GNC: $273 \pm 59.7$ ) and biological (GB: $288.6 \pm 74.6$ ) were similar $(\mathrm{p}>0.05)$ and significantly higher than those obtained by in situ (GIS: $166.2 \pm 45.9$ ) and chemical (GC:

Table 1. Means and standard deviations $\left(\mathrm{mean}_{ \pm} \mathrm{SD}\right)$ of surface hardness values before $\left(\mathrm{SH}_{1}\right)$ (sound dentin) and after $\left(\mathrm{SH}_{2}\right)$ the artificial caries development and natural lesions.

\begin{tabular}{lcc}
\hline Group & $\mathrm{SH}_{1}$ & $\mathrm{SH}_{2}$ \\
\hline $\mathrm{GB}$ & $75.11 \pm 3.2 \mathrm{Aa}$ & $5.43 \pm 0.7 \mathrm{Bb}$ \\
$\mathrm{GC}$ & $75.95 \pm 2.5 \mathrm{Aa}$ & $12.08 \pm 0.6 \mathrm{Ba}$ \\
$\mathrm{GIS}$ & $75.88 \pm 5.5 \mathrm{Aa}$ & $11.47 \pm 0.3 \mathrm{Ba}$ \\
$\mathrm{GNC}$ & - & $5.64 \pm 0.1 \mathrm{~b}$ \\
\hline
\end{tabular}

Same lowercase letters in collum mean no statistically significant difference among groups, according to unpaired t-test ( $p>0.05)$. Same uppercase letters in $r$ ow mean no statistically significant difference among groups, according to paired t-test ( $p>0.05)$. 
166.4 \pm 23.4$)$ models. Specimens showed well delimited alterations from the outer to inner layers of dentin in caries lesions produced by biological model and natural caries lesions. Image obtained for chemical and in situ caries lesions were also visible, but there was no clear difference between carious and sound dentin (Fig. 2).

\section{Discussion}

Most of the understanding about dentin properties and its relationship with dental materials, dentin bonding and the factors that influence the dentin/adhesive interface, was based on studies conducted mostly in noncarious human dentin $(1,18)$. However, this is not the clinically most frequently observed clinically. On the other hand, dentists are restoring teeth with different carious lesion patterns, and recently the deep caries lesion treatment has been questioned concerning the amount of tissue removal. Some studies showed that nowadays it is acceptable to leave behind caries-affected or even caries-infected dentin during the restorative procedures, but the characteristics of dentin substrate influence directly the bond strength of the dentin/adhesive interface $(1,18)$.

The hypothesis tested in the present study was partially accepted. It was observed that some models of dentinlike caries development provided different patterns of microharness, depth, inorganic and organic content and structure, compared to natural caries lesions. Biological model was more similar to natural caries lesions with respect to the analysis perfomed. These results could be observed by surface and cross-sectional microhardness, FT-Raman, $\mu$ EDXRF and SEM analyses.

It has been assumed that surface and cross-sectional microhardness may reflect indirectly the inorganic content of dental substrate and this is widely used in dental caries studies (18). Thus, results obtained could be a result of higher demineralization produced by $S$. mutans contacting the broth supplied with sucrose and glucose and low pH (4.0) presented during the period of the study ( 14 days). In spite of this, these carbohydrates are a source of nutrients for S. mutans acid production without interval for treatment or demineralization/remineralization process, providing a mineral unsaturated environment leading to a continuous demineralization (18). This process provided a dentin caries-like lesion with an evident infected layer, simulating a substrate observed before caries removal. Furthermore, it also showed similar less-radiolucent surface zones

Table 2. Mean values of cross-sectional microhardness (CSH), considering different depths and groups

\begin{tabular}{lcccccccc}
\hline \multirow{2}{*}{ Group } & \multicolumn{7}{c}{ Depths $(\mu \mathrm{m})$} \\
\cline { 2 - 9 } & 10 & 30 & 50 & 70 & 90 & 110 & 220 & 330 \\
\hline $\mathrm{GB}$ & $6.83 \mathrm{aA}$ & $8.98 \mathrm{aB}$ & $12.71 \mathrm{aC}$ & $16.27 \mathrm{aCD}$ & $21.24 \mathrm{aDE}$ & $24.98 \mathrm{aEF}$ & $31.83 \mathrm{aEF}$ & $41.68 \mathrm{aF}$ \\
$\mathrm{GC}$ & $10.91 \mathrm{bA}$ & $13.95 \mathrm{bAB}$ & $18.39 \mathrm{bBC}$ & $23.79 \mathrm{bCD}$ & $31.40 \mathrm{aDE}$ & $35.04 \mathrm{aDE}$ & $41.75 \mathrm{aE}$ & $50.05 \mathrm{aE}$ \\
$\mathrm{GIS}$ & $8.15 \mathrm{cA}$ & $11.59 \mathrm{abB}$ & $15.78 \mathrm{abBC}$ & $20.39 \mathrm{abCD}$ & $25.03 \mathrm{aDE}$ & $34.64 \mathrm{aEF}$ & $38.58 \mathrm{aEF}$ & $46.00 \mathrm{aF}$ \\
$\mathrm{GNC}$ & $7.71 \mathrm{acA}$ & $10.23 \mathrm{aB}$ & $13.98 \mathrm{abC}$ & $18.70 \mathrm{abCD}$ & $24.35 \mathrm{aDE}$ & $31.00 \mathrm{aEF}$ & $36.67 \mathrm{aEF}$ & $44.39 \mathrm{aF}$
\end{tabular}

Same lowercase letters in column (comparison among groups at the same depth) mean no statistically significant difference, according to two-way ANOVA and Tukey tests ( $>0.05$ ). Same uppercase letters in rwo (comparison of depths in the same group) mean no statistically significant difference, according to two-way ANOVA and Tukey tests ( $p>0.05)$.

Table 3. Integrated area values (mean $\pm \mathrm{SD}$ ) of phosphate, carbonate, type 1 collagen and $\mathrm{CH}$ bonds of dentin content assessed by Raman shifts, and weight percentages $(\mathrm{wt} \%)\left(\mathrm{mean}_{ \pm} \mathrm{SD}\right)$ of calcium $(\mathrm{Ca})$ and phosphorus $(\mathrm{P})$ obtained by $\mathrm{X}$-ray fluorescence point measures, considering caries development models and natural lesions

\begin{tabular}{|c|c|c|c|c|c|c|}
\hline \multirow{2}{*}{ Group } & \multicolumn{3}{|c|}{ Raman shifts* } & \multicolumn{3}{|c|}{$\mathrm{X}$-ray fluorescence ${ }^{* *}$} \\
\hline & Phosphate & Carbonate & Type 1 collagen & $\mathrm{CH}$ bonds & $\mathrm{Ca}$ & $P$ \\
\hline GB & $59.12 \pm 7.6$ a & $59.11 \pm 5.1 \mathrm{a}$ & $108.61 \pm 18.1 \mathrm{a}$ & $159.73 \pm 1.5 \mathrm{a}$ & $4.86 \pm 2.1 \mathrm{c}$ & $1.42 \pm 1.1 \mathrm{c}$ \\
\hline GC & $57.72 \pm 10.2 \mathrm{a}$ & $67.97 \pm 4.6 \mathrm{a}$ & $67.83 \pm 22.5 \mathrm{~b}$ & $144.70 \pm 23.6 \mathrm{a}$ & $20.56 \pm 1.6 \mathrm{ab}$ & $10.48 \pm 0.8 \mathrm{ab}$ \\
\hline GIS & $58.74 \pm 8.3$ a & $71.50 \pm 3.6 \mathrm{a}$ & $90.16 \pm 11.0 \mathrm{a}$ & $159.30 \pm 1.8 \mathrm{a}$ & $24.06 \pm 3.8$ a & $12.18 \pm 1.9 \mathrm{a}$ \\
\hline GNC & $55.55 \pm 4.1 \mathrm{a}$ & $56.75 \pm 7.6 \mathrm{a}$ & $108.49 \pm 14.8 \mathrm{a}$ & $158.44 \pm 3.4 \mathrm{a}$ & $11.58 \pm 10.1 \mathrm{bc}$ & $5.38 \pm 5.7 \mathrm{bc}$ \\
\hline
\end{tabular}

*Raman shifts: Same lowercase letters in collum mean no statistically significant difference, according to one-way ANOVA and Dunnett multiplecomparisons tests $(p>0.05)$. ${ }^{* *} X$-ray fluorescence: Same lowercase letters in column mean no statistically significant difference, according to one-way ANOVA and Dunnett multiple-comparisons tests ( $p>.05)$. 

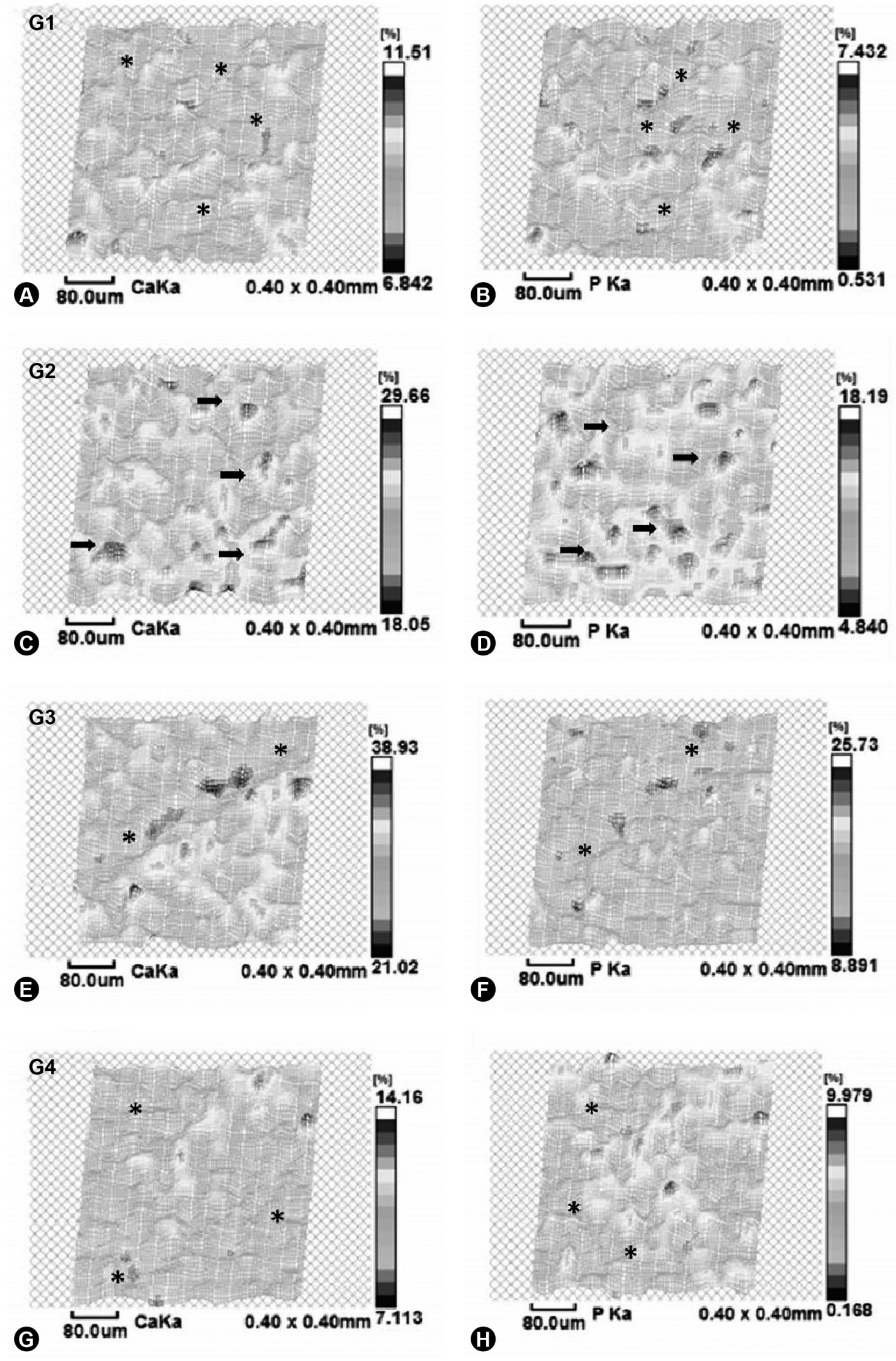

Figure 1. Dentin caries depth values $(\mu \mathrm{m})$ regarding different caries lesions. Mapping results panel of calcium (A, C, E, G) and phosphorous (B, D, F, H) obtained by X-ray fluorescence of specimens in groups GB (Biological model), GC (Chemical model), GIS (In situ model) and GNC (Natural caries). Mapping results showed more similarity among groups GB and GNC, followed by GIS, presenting a less mineralized area ${ }^{*}$ ), and differed from GC, presenting a greater mineralized area (arrow ). 
above the more-radiolucent lesion body, like the naturally produced dentin lesion (3). Higher SH and CHS values obtained for the chemical and in situ models probably occurred because dentin caries developed with acid gel (4) promote a superficial demineralization producing a thicker layer. The in situ model mimicks not only a multi-factorial environment for dental caries, including formation of biofilm with cariogenic potential, a carbohydrate challenge, either experimentally controlled or provided by the subject's diet, and time determined by experimental period length, but also maintain the fluoride levels $(15,16)$.

It was demonstrated that the static models, such as solution and gel, produce dentin lesions that resemble histologically natural caries lesion, with a well mineralized outer surface followed by an area of increased demineralization, which agrees with the results of crosssectional microhardness observed in the present study. Actually, it has been suggested that impurities in some gel-based models were responsible for the subsurface lesion pattern. This similarity was found until $50 \mu \mathrm{m}$ in depth. In this depth, all caries lesions began to present similar microhardness values, which suggests that after this depth they may present little dentin (3).

SEM images showed that carious lesions produced by biological and natural models were more aggressive, as already described. The biological model reproduces some characteristics described for natural dentin caries, such as color and presence of two distinct layers (4), developing deeper lesions and causing a higher demineralization in dentin structure compared to the chemical and in in situ models (Figs. 2A and 2B), which produced thinner lesions (Fig. 2C). This could be explained because the chemical model had a $5.0 \mathrm{pH}$ during the study and produced superficial demineralization and the in situ model could overtake a de- and remineralization process (7).

Otherwise, caries-like lesions produced by in situ model have external factors that may contribute to a possible remineralization process, as the influence of organic content in natural saliva and S. Mutans count, reducing the severity of carious lesion produced, and were maintained at minimum pH around 5.5 (1). Thus, a laboratory model cannot produce biological responses that may occur in vivo, such as dead tracts, mineralized tubules or secondary dentin. However, despite these differences, caries-like lesions produced by the biological model presented a defined structure more similar to the natural carious lesion (13).

Concerning EDX spectroscopy, the results showed that caries-like lesions produced by biological and chemical models were similar to natural caries lesion with similar values of calcium and phosphorus. The chemical model presented similar results in this analysis due perhaps to the gel components and superficial mineral loss, and the in situ model led to a high percentage of minerals compared with other groups. The last one was involved in an in vivo
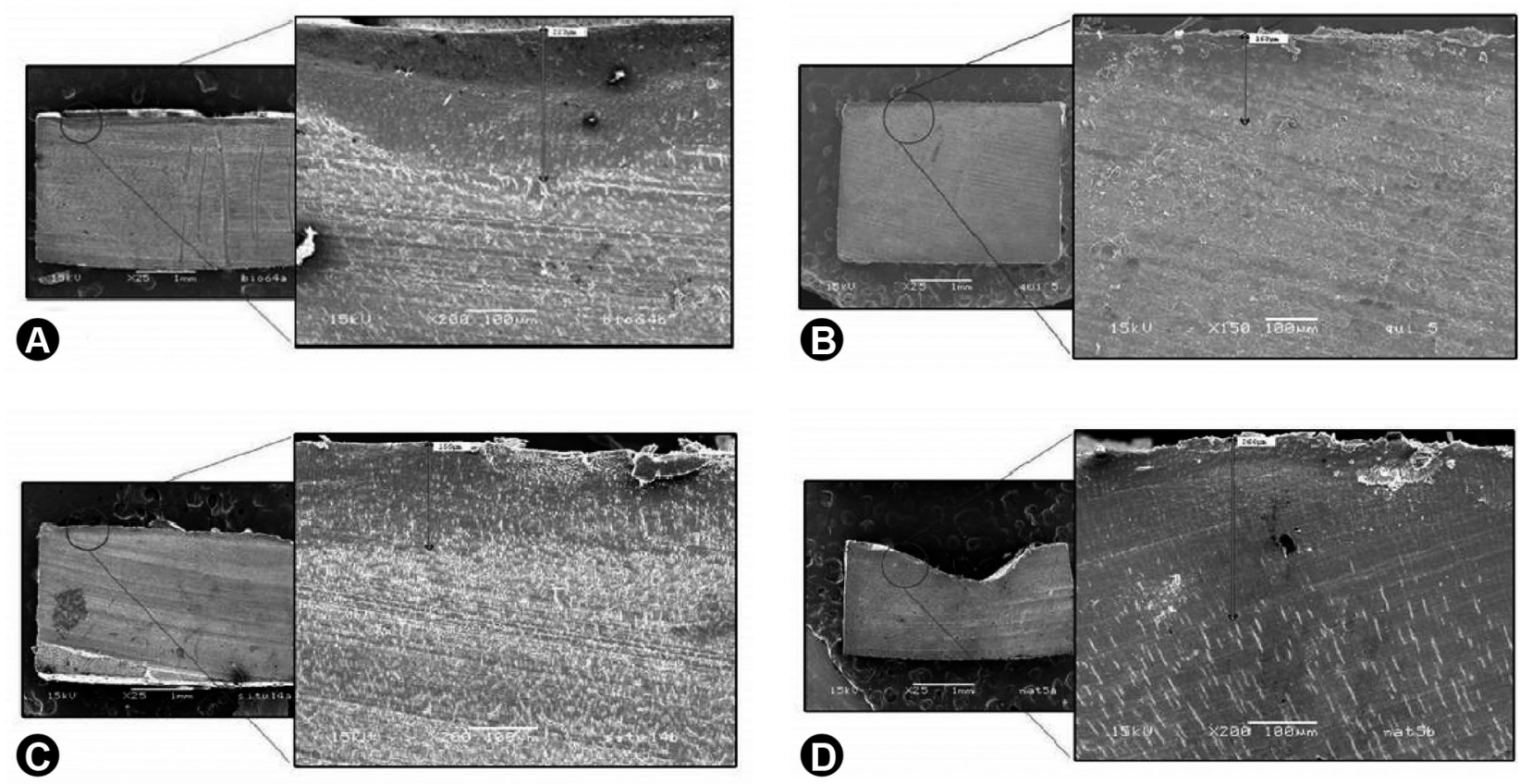

Figure 2. Representative micrographys from dentin caries lesions. Circle shows the depthest dentin caries lesion region that was measured in the specimen, shown in the highest magnification $(200 \times)$ on the right side. (A) dentin caries lesion produced by biological model, (B) dentin caries lesion produced naturally in oral cavity, note the different surfaces over the lesion length, (C) dentin caries lesion produced by in situ model, (D) dentin caries lesion produced by the chemical model. 
situation which is far more complicated for involving eating habits, presence of physiologically secreted saliva, biofilm of varying composition and thickness, and a pellicle-coated tooth surface, which can be variable (23).

The biological model presents an opportunity to compare the cariogenic potential of different bacterial strains or mixed bacterial populations, to assess the cariogenicity of foods, and investigate the etiology and prevention of enamel and dentin caries (3).

Finally, concerning the mineral contents, FT-Raman spectroscopy showed no difference among all groups as phosphate and carbonate values, even regarding $\mathrm{CH}$ bonds. A significant difference could only be observed for collagen type I values. Caries-like lesions produced by chemical model showed lower values compared to other models. Natural caries-like lesions were similar to lesions produced by biological and in situ models. FT-Raman results could differ from the other analyses ( $\mathrm{SH}, \mathrm{CSH}, \mathrm{SEM}$ and $\mu \mathrm{EDX}$ ) possibly because $\mathrm{FT}$-Raman laser can penetrate to greater depth than the produced caries-like lesions, but does not mean that these substrates had no difference, they did have differences on the surface $(10$ and $30 \mu \mathrm{m})(4,24)$.

Although some tests showed that caries lesions produced by chemical model were similar to natural caries, it did not show the same morphological features of natural caries lesion observed by SEM. It was different from what was observed in the caries-like lesions produced by biological model (with an infected layer and an affected inner layer). It may be applied to partial caries removal techniques and current studies of minimal intervention dentistry.

In conclusion, considering all analyses employed in the present study, caries-like lesion produced by biological model was the closest to the natural caries lesion.

\section{Resumo}

Este estudo avaliou as caracteristicas estruturais e moleculares da lesão de cárie artificial em dentina produzidas por diferentes modelos artificiais (LCA) comparados à lesão de cárie natural (LCN). Cento e vinte e quatro blocos de dentina oclusal hígida e 47 blocos cariados foram obtidos e a dureza superficial foi analisada (SH1). Eles foram divididos em grupos de acordo com os modelos de LCA: GB: Biológico; GQ: Químico; GIS: In situ; GCN: lesão de cárie natural (controle). Blocos dos grupos 1, 2 e 3 foram submetidos à produção da lesão de cárie. Blocos de dente contendo LCA e LCN foram submetidos à análise de dureza superficial (SH2), análise FT-Raman e $\mu$ EDXRF. Em seguida, todos os blocos foram seccionados longitudinalmente e uma das metades foi submetida à análise da dureza transversal (CSH) e outra à análise em microscopia eletrônica de varredura (MEV). Dados da SH1 e SH2 foram submetidos ao teste $t$ (não-pareado e pareado, respectivamente). Dados do CSH e MEV foram submetidos à ANOVA a um fator e teste Tukey e ANOVA a um fator e teste $t$, respectivamente $(p<0,05)$. Dados do FT-raman $/ \mu$ EDXRF foram submetidos a ANOVA a um fator e teste de Dunnett para múltiplas comparações $(p<0,05)$. GB e $G C N$ apresentaram os menores valores de $\mathrm{SH} 2$ que foram significativamente diferentes de GC e GIS. Quanto a CSH, $\mathrm{GB}$ e GCN mostraram nenhuma diferença significativa entre eles. SEM mostrou profundidade de lesão de cárie semelhante para GB e GCN, sendo significativamente maior que para GC e GIS. $\mu$ EDXRF mostrou valores similares de cálcio e fosfato para $\mathrm{GB}$ e $\mathrm{GCN}$, enquanto os valores do GCN foram significativamente diferentes em relação ao GIS. Nenhuma diferença significativa foi encontrada entre os grupos em relação aos valores de fosfato, carbonato e ligações $\mathrm{CH}$. Para o colágeno tipo I, os valores do GC foram significativamente diferentes em comparação aos outros grupos. Pode-se concluir que a cárie artificial produzida pelo GB foi o mais próximo da LCN.

\section{Acknowledgements}

This research was supported by FAPESP - São Paulo Research Support Foundantion (grant numbers 08/02331-6, 01/14384-8, 05/50811-9). The authors are grateful to Pediatric Dentistry Department, Dental Materials (Piracicaba Dental School - University of Campinas) and Laboratory of Biomedical Vibrational Spectroscopy (University of Vale do Paraiba) for their cooperation and to Mr Marcos Cangiani, Marcelo C Maistro, Adriano Martins for been helpful during the developing of this study.

\section{References}

1. Marshall GW, Habelitz S, Gallagher R, Balooch M, Balooch G, Marshall SJ. Nanomechanical properties of hydrated carious human dentin. J Dent Res 2001;80:1768-1771.

2. Zheng L, Hilton JF, Habelitz S, Marshall SJ, Marshall GW. Dentin caries activity status related to hardness and elasticity. Eur J Oral Sci 2003;111:243-252.

3. Clarkson BH, Wefel JS, Miller I. A model for producing caries-like lesions in enamel and dentin using oral bacteria in vitro. J Dent Res 1984;63:1186-1189.

4. Arends J, Ruben JL, Inaba D. Major topics in quantitative microradiography of enamel and dentin: $R$ parameter, mineral distribution visualization, and hyper-remineralization. Adv Dent Res 1997;11:403-414.

5. Marquezan M, Corrêa FN, Sanabe ME, Rodrigues Filho LE, Hebling J, Guedes- Pinto AC, et al.. Artificial methods of dentin caries induction: a hardness and morphological comparative study. Arch Oral Biol 2009;54:1111-1117.

6. Pugach MK, Strother J, Darling CL, Fried D, Gansky SA, Marshall SJ, et al.. Dentin caries zones: mineral, structure and properties. J Dent Res 2009;88:71-76.

7. Carvalho FG, Fucio SBP, Sinhoreti MAC, Correr-Sobrinho L, PuppinRontani RM. Confocal laser scanning microscopic analysis of depth of dentin caries-like lesions in primary and permanent teeth. Braz Dent J 2008;19:139-144.

8. Sacramento PA, De Carvalho FG, Pascon FM, Borges AF, Alves MC, Hosoya $\mathrm{Y}$, et al.. Influence of $\mathrm{NaOCl}$ irrigation and water storage on the degradation and microstructure of the resin/primary dentin interface. J Adhes Dent 2011;13:213-220.

9. Elgalaid TO, Creanor SL, Creanor S, Hall AF. The permeability of artificial dentin carious lesions. Arch Oral Biol 2008;53:744-750.

10. ten Cate JM, Duijsters PP. Alternating demineralization and remineralization of artificial enamel lesions. Caries Res 1982;16:201210.

11. Hsu KW, Marshall SJ, Pizon LM, Watanabe L, Saiz E, Marshall G. SEM evaluation of resin-carious dentin interfaces formed by two dentin adhesive systems. Dent Mater 2008;24:880-887.

12. Rodrigues $E$, Delbem AC, Pedrini D, Cavassan L. Enamel remineralization by fluoride-releasing materials: proposal of a $\mathrm{pH}$-cycling model. Braz Dent J 2010;21:446-451.

13. Rehder-Neto FC, Turssi CP, Serra MC. Erosion-like lesions progression in human and bovine enamel. Int J Dent 2010;9:16-20.

14. Seemann R, Bizhang M, Kluck I, Loth J, Roulet JF. A novel in vitro microbial-based model for studing caries formation-development and initial testing. Caries Res 2005;39:185-190.

15. ten Cate JM. In situ models, physical-chemical aspects. Adv Den Res 1994;8:125-133.

16. Zero DT. In situ caries models. Adv Den Res 1995;9:214-230.

17. Nakajima M, Kitasako Y, Okuda M, Foxton RM, Tagami J. Elemental distributions and microtensile bond strength of the adhesive interface 
to normal and caries-affected dentin. J Biomed Mater Res B Appl Biomater 2005;72:268-275.

18. Haj-Ali R, Walker M, Williams K, Wang Y, Spencer P. Histomorphologic characterization of noncarious and caries-affected dentin/adhesive interfaces. J Prosthodont 2006;15:82-88.

19. Perdigão J. Dentin bonding-variables related to the clinical situation and the substrate treatment. Dent Mater 2010;26:e24-37.

20. White JM, Goodis HE, Marshall SJ, Marshall GW. Sterilization of teeth by gamma radiation. J Dent Res 1994;73:1560-1567.

21. Boeckh C, Schumacher E, Podbielski A, Haller B. Antibacterial activity of restorative dental biomaterials in vitro. Caries Res 2002;36:101-107.

22. Kuramoto A, Imazato $S$, Walls AWG, Ebisu S. Inhibition of root caries progression by an antibacterial adhesive. J Dent Res 2005;84:89-93.

23. Cury JA, Francisco SB, Del Bel Cury AA, Tabchoury CP. In situ study of sucrose exposure, mutans streptococci in dental plaque and dental caries. Braz Dent J 2001;12:101-104.

24. Soares $L E$, do Espírito Santo $A M$, Junior $A B$, Zanin $F A$, da Silva Carvalho $C$, de Oliveira $R$, et al.. Effects of Er: YAG laser irradiation and manipulation treatments on dentin components, Part 1: Fourier transform-Raman study. J Biomed Opt 2009;14:024001.

25. Pascon FM, Kantovitz KR, Soares LE, Santo AM, Martin AA, PuppinRontani RM. Morphological and chemical changes in dentin after using endodontic agents: Fourier transform Raman spectroscopy, energydispersive $\mathrm{x}$-ray fluorescence spectrometry, and scanning electron microscopy study. J Biomed Opt 2012;17:075008.

Received August 21, 2013 Accepted November 29, 2013 